\title{
REVIEW
}

\section{Chemical adaptations in the Octocorallia: evolutionary considerations}

\author{
Paul W. Sammarco ${ }^{1}$, John C. Coll ${ }^{2}$ \\ ${ }^{1}$ Louisiana Universities Marine Constortium (LUMCON), Chauvin, Louisiana 70344, USA \\ ${ }^{2}$ Chancellory, University of Central Queensland, Rockhampton, Queensland 4702, Australia
}

\begin{abstract}
The Octocorallia are a highly diverse group, rich in secondary compounds which serve several ecological functions, including predator defense, interspecific competition for space, antifouling, and reproduction. The Alcyonacea are characterized by high frequencies of ichthyotoxicity and feeding deterrence which are not generally correlated with each other. This may be due to the multiple functions these compounds perform, masking correlations which would otherwise be apparent. Correlations between ichthyotoxicity and physical defense exist, but only at higher levels of taxonomic resolution. One resultant selective advantage of variance in ichthyotoxicity and feeding deterrence may be Diffuse Batesian Mimicry, whereby the toxic or feeding-deterrent characteristics of a majority of species help to protect a taxon with a small number of general morphological types and small variance in coloration from generalist predators. Surface-brooded planulae of Indo-Pacific coral species, similar in appearance but not possessing toxic or feeding deterrent attributes, may be similarly protected. The chemical characters of octocorals may serve the same functions which morphological characters in scleractinian corals serve, particularly in predator defense and competition for space. Most octocorals lack a rigid skeleton possessed by scleractinians, which can protect polyps from predation. Octocorals also lack toxic stinging nematocysts common to scleractinians, but possess allelopathic capabilities. In some octocorals, 'non-toxic' nematocysts on sweeper tentacles may still be effective in competition for space; in others, aggressive interactions can be avoided through re-orientation or movement, resulting in directed growth. Octocoral orders are distributed inequitably between the tropical Atlantic and Indo-Pacific. The Gorgonacea dominate the former; the Alcyonacea, the latter. Octocoral species diversity is higher in the western Indo-Pacific, as is the abundance and diversity of secondary metabolites and their functions. This may be a result of differential levels of extinction between the 2 regions during the early Miocene and the late Pliocene/early Pleistocene, with high extinction rates having been experienced in the Caribbean. These extinctions may also have affected radiation in the secondary metabolites produced by those species and the functions which those metabolites serve. Secondary metabolites appear to have contributed to the evolutionary success of the Indo-Pacific Alcyonacea. In accordance with the Time-Stability hypothesis, we believe that this high abundance and diversity evolved in the Indo-Pacific under conditions of reduced climatic change and lower extinction levels, when compared to the Caribbean.
\end{abstract}

\section{INTRODUCTION}

Coral reefs are among the most ancient structures on earth built by living organisms. Although many people associate coral reefs with hard or scleractinian corals, in the Indo-West Pacific, soft corals or octocorals can dominate many reefs (Benayahu \& Loya 1977, Nishihira 1981, Dinesen 1983). Most of these octocorals belong to the order Alcyonacea, a highly diverse group of benthic colonial invertebrates. In the Caribbean, a similar co-dominance can occur between scleractinians and octocorals, but the major octocoral representatives there are the Gorgonacea, including the sea fans and sea whips - highly flexible, often branched sessile epifauna (Bayer 1957, Wells 1957). 
One of the reasons for the evolutionary success of alcyonaceans in the Indo-West Pacific is considered to be the high levels of secondary metabolites commonly found in their tissues (Tursch et al. 1978, Coll 1981). The types and concentrations of these compounds vary greatly between species (Faulkner 1977, 1984, 1986, 1987, 1988, 1990, 1991). These compounds are now known to play a number of ecological roles in these organisms (Bakus et al. 1986, Sammarco \& Coll 1988).

Here, we review and discuss some aspects of the chemical ecology of the Octocorallia, particularly the Alcyonacea and Gorgonacea, and how it has contributed to the evolutionary success of this taxon. The primary factors we will cover fall into 4 categories: (1) the role of secondary compounds in defense against predation, competition for space, anti-fouling, and enhancement of reproduction; (2) mimicry as a broad predator defense mechanism, assisting in protection of the order Alcyonacea as a whole; (3) secondary compounds in the Alcyonacea as functional equivalents to certain defense characters in the Scleractinia; and (4) high species diversity in the Alcyonacea as it relates to the high diversity of alcyonacean toxins, the variety of their functions, and their biogeographic distribution.

\section{FUNCTIONS OF SECONDARY METABOLITES IN OCTOCORALS}

\section{The Alcyonacea}

Predator defense

A high proportion (ca $60 \%$ ) of the soft corals on the Great Barrier Reef are ichthyotoxic (Coll et al. 1982b, Coll \& Sammarco 1983, authors' unpubl. data). Here, ichthyotoxicity is defined as toxic to standard test fish (Gambusia affinis) exposed to crude aqueous extracts of a soft coral (sensu Yamanouchi 1955). Effects noted in test fish range from respiratory stress through disorientation to mortality. This is admittedly a simple test but has served well as an indicator of the presence of cytotoxic or other bio-active molecules.

The soft coral Sinularia flexibilis contains a range of diterpenes, which vary in concentration from collection to collection. With this species, only 11,12-deoxyflexibilide (Fig. 1,1) is ichthyotoxic to any appreciable extent (Y. Uchio et al. pers. comm.). (We will refer back to other compounds from S. flexibilis later in the review.)

Further tests with Gambusia affinis and these aqueous soft coral extracts have demonstrated that ca $75 \%$ of these extracts possess feeding deterrent characteristics. Strangely enough, this deterrence, whether via taste, olfaction or gustatory cues, does not appear to be correlated with ichthyotoxicity as assessed by these naive predators (La Barre et al. 1986a). Thus, we believe that there are a number of synergistic factors which may be acting to alter the perception of taste in the test fish.

Sinularia flexibilis possesses significant feeding deterrence, and a second metabolites derived from it, dihydroflexibilide (Fig. 1,2), has been recently identified as being responsible for this character (T. Aceret pers comm.). In the case of Sinularia maxima, Wylie \& Paul (1989) identified diterpene (Fig. 1,3) as an ichthyodeterrent.

Some toxic secondary compounds produced by alcyonacean soft corals are actually sequestered and stored by specialist predators and used for their defense. One example is the molluscan predator, Phyllodesmium longicirra (Coll et al. 1985). These and other selective predators may possibly be attracted to soft coral colonies by their toxic terpenoids (Hadfield \& Ciereszko 1978), which may also stimulate egglaying in certain molluscs such as Ovula ovum. This mollusk consumes (Coll et al. 1983) and lays eggs on (K. Muzik pers. comm.) toxic soft corals of the genus Sarcophyton.

Ichthyotoxicity in the Alcyonacea is negatively correlated with the occurrence of certain physical morphological attributes specifically associated with antipredator defense (Sammarco et al. 1987); that is, the presence of toxicity may be associated with the absence of physical defense against predators. This relationship only becomes clear, however, at high levels of taxonomic resolution (at the genus level, or within selected families). Such physical characters include polypary armament, micro-armament of the individual polyp, and mineralization of the coenenchyme.

\section{Competition for space}

Terpenoid secondary metabolites function as allelopathic agents in interspecific competition for space in certain alcyonaceans (Sammarco et al. 1983). They can cause tissue necrosis and growth inhibition in scleractinian corals both through direct tissue-to-tissue contact or through the water column in the absence of contact (Coll et al. 1982a). In the case of Sinularia flexibilis, the active allelopathic agents are dihydroflexibilide (Fig. 1,2), and the more potent flexibilide (Fig. 1,4). The effectiveness of the allelopathic compounds responsible for these deleterious responses varies greatly between species. The susceptibility of the competing species to the released toxins is also highly speciesspecific, whether the competitor for space is a scleractinian or another alcyonacean coral (Sammarco et al. 1985. La Barre et al. 1986b). These important chemically mediated competitive abilities in the Alcyonacea 


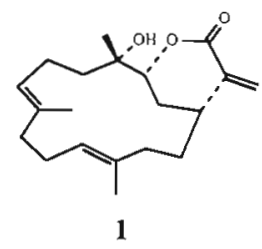

11.12-dcoxyflexıbilide

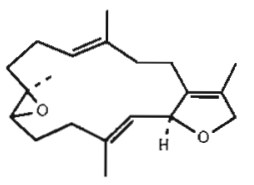

5

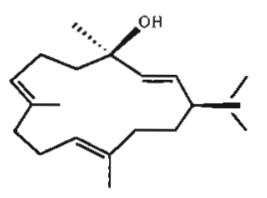

epi-thunbergol

9

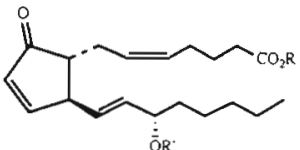

$14 \quad \mathrm{R}=\mathrm{CH}_{3} \quad \mathrm{R}^{\prime}=\mathrm{AC}$

15R-PGA 2 derivatives

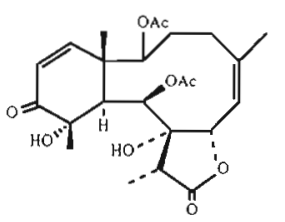

19

renillafoulins-A

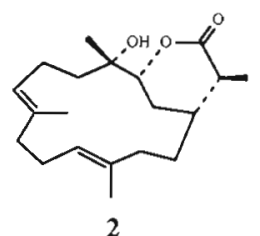

dihydroflexibilide
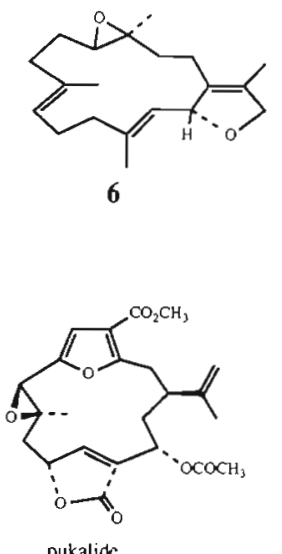

10<smiles>C[C@]1(Cl)C[C@](C)(/C=C/Cl)[C@H](Cl)C[C@@H]1Cl</smiles>

7

chloromencnsine

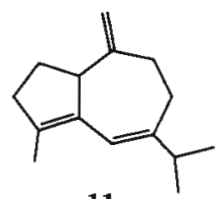

11

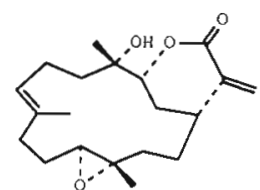

4

flexibilide

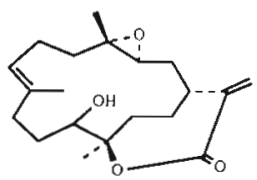

8

sınulariolide<smiles>CC1=C2C=CCC[C@@H](C)C2CC1</smiles>

12

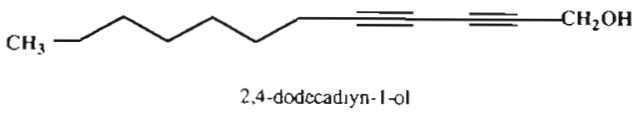

13<smiles>C=C1C(=O)O[C@H]2[C@@H]1C[C@H]([C@H](C)CCC/C=C\CCC(C)(C)O)[C@H]2C</smiles>

15

eunicin<smiles>CC1=CCC(O)[C@](C)([C@H](O)CC/C(C)=C\C2OC(=O)C(C)=C2C)[C@@H]1C</smiles>

20

brianthein-W

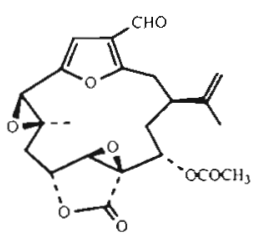

16

lophotoxin

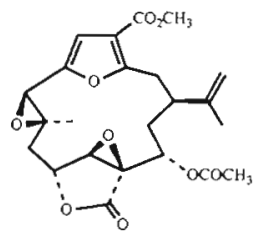

21

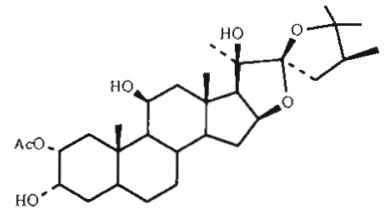

17

hippurin-1<smiles>C[n+]1ccccc1C(=O)[O-]</smiles>

18

homarine

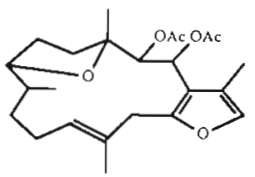

22

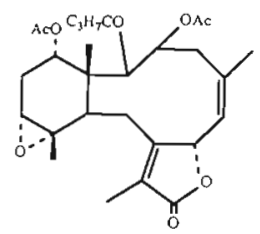

23<smiles>CC1CCC(C)C2C(C)CCC(C)C12</smiles>

24

palustrol<smiles>N=C(N)N/C=C/c1ccc(O)c(O)c1</smiles>

25 tubastrine
Fig. 1. Chemical structure of various secondary metabolites in octocorals 
may be enhanced by various behavioural and physiological adaptations. Such adaptations may include: (1) alteration of internal hydrostatic pressure to cause bending of the organism away from its competitor; (2) the secretion of a polysaccharide cuticle to protect itself against its competitors' offensive or defensive mechanisms; (3) redirected growth away from and sometimes over its competitor (La Barre \& Coll 1984, La Barre et al. 1986b), and (4) sweeper tentacles in some Caribbean (Sebens \& Miles 1988) and IndoPacific (Alino 1989) gorgonaceans.

In addition, predation and environmental factors such as food, light, and turbidity may exert control over competitive balance between certain species of octocorals and scleractinians, whether chemically mediated or not. In the central region of the Great Barrier Reef, it appears that higher nutrient concentrations in inshore waters may have created a situation where environmental conditions slightly enhance growth rates and competitive advantage in the octocoral Clavularia inflata over even the fastest growing scleractinian corals, such as Acropora longicyathus. This competitive trend can be reversed between certain species if the competing pair is transplanted to mid-shelf waters where nutrient concentrations and related conditions (turbidity, zooplankton, density, etc.) are reduced. Thus, competition for space in octocorals is also subject to variance depending upon environmental factors (Alino et al. 1992).

\section{Anti-fouling}

A range of cembranoid diterpenes, including Structures 5 and 6 (Fig. 1), has been shown to inhibit growth of the common filamentous alga Ceramium codii, observed in the field to attach to the polypary of alcyonacean soft corals (Coll et al. 1987). This process, however, is not entirely one way. Recent investigations of associations between soft corals and the red alga plocamium hamatum have revealed that the chlorinated monoterpene, chloromertensine (Fig. 1,7) present in this alga can kill the soft coral Sinularia cruciata (Coll et al. 1988, De Nys et al. 1991). This same compound also exhibits anti-feedant and anti-fouling properties (Hay et al. 1989).

In Sinularia flexibilis, sinulariolide (Fig. 1,8) is capable of inhibiting algal overgrowth, as shown by laboratory experiments (Tursch et al. 1978).

\section{Reproduction}

A range of secondary metabolites also appears to play an important role in reproduction in the alcyonaceans. Certain diterpenes (e.g epi-thunbergol and pukalide,
$9 \& 10$ respectively of Fig. 1) are present in the eggs of the alcyonaceans Lobophytum compactum and Sinularia abrupta, respectively; yet they cannot be detected in the tissue of the parent colony (Bowden et al. 1985, Coll et al. 1989). These egg-specific terpenes do not appear to be effective anti-feedants against reef fish, as fish consume large amounts of the eggs; nor are they effective antibiotics against marine bacteria (Alino 1989).

Recent evidence suggests that they play a role in spawning. Both epi-thunbergol and pukalide stimulate polyp contraction and thus egg release (Pass et al. 1989). Additional recent experimentation has demonstrated that epi-thunbergol is the active vector in sperm chemotaxis within Lobophytum compactum (Coll pers. comm.). In other cases (e.g. Clavularia inflata), sesquiterpenes and their degradation products, such as Structures 11 and 12 (Fig. 1), have been implicated as anti-feedants in protecting externally brooded eggs (Coll et al. 1988). Preliminary investigations have also identified a lipid-derived molecule, 2,4-dodecadiyn-1-ol (Fig. 1,13), as the principal sperm attractant in the scleractinian coral Montipora digitata (Coll et al. 1990).

The multiplicity of functions identified for secondary metabolites in the Alcyonacea make it nearly impossible to predict their function in any given species (Sammarco \& Coll 1990).

\section{The Gorgonacea}

\section{Predator defense}

Toxicity has been well documented in the Gorgonacea. Data on the frequency and distribution of this character in this group, however, have not yet been collated; thus, a complete, direct comparison between the Alcyonacea and Gorgonacea in this regard would be difficult.

Studies of gorgonacean octocorals have implicated toxic secondary metabolites in defense against predators (Ciereszko \& Karns 1973, Pawlik et al. 1987). Prostaglandins (e.g. Fig. 1,14) have been shown to be effective feeding deterrents against a range of reef fish (Gerhart 1984), while toxic cembranolides (e.g. Fig. 1,15) have been postulated to play an antipredatory role in other gorgonians (Lee et al. 1981). Lophotoxin (Fig. 1,16), a highly toxic terpenoid, is derived from the aposymbiotic sea whip Lophogorgia chilensis, and has been implicated in defense against predators in this species (Fenical et al. 1981). Novel steriodal metabolites, such as hippurin-1 (Fig. 1,17), have been isolated from Isis hippuris, a gorgonian from the Great Barrier Reef (Kazlauskas et al. 1977). Their ecological and/or physiological functions within the organism, however, are not known. 
Toxic terpenoids are distributed within a single gorgonian colony unevenly. Concentrations are apparently higher in those portions of the colony which receive higher intensities of predation, particularly the thin, polyp-rich, terminal branchlets (Harvell et al. 1988, Harvell \& Fenical 1989).

\section{Competition for space}

Competition in gorgonaceans has not been studied extensively. Encrusting morphs, such as some of the Erythropodium spp., can dominate certain habitats on Caribbean reefs and can readily overgrow scleractinian corals and other sessile epibenthic organisms (Karlson 1980). The majority of gorgonians, however, are erect in form, greatly reducing the need for expansion in 2-dimensional space - a common requirement in encrusting forms.

With respect to the erect forms, whip corals or holaxonians can cause tissue necrosis upon contact with their hetero-specific neighbours (Theodor 1966, 1971, 1975). It has not been confirmed, however, that this response is caused by allelochemical agents. The Gorgonacea are known to be rich in secondary compounds (Faulkner 1977, $1984,1986,1987,1988,1990,1991$ ) which, based upon the data available to date, appear to function primarily as anti-predator or anti-fouling (see below) agents.

Encrusting gorgonians, like Briareum and Erythropodium species (Karlson 1980), utilize rapid growth rates and possibly specially adapted tentacles, similar to the sweeper tentacles of certain scleractinians, to expand their living space (Sebens \& Miles 1988, Alino 1989, Alino et al. 1992).

\section{Anti-fouling}

Various Caribbean gorgonians have exhibited antifouling characteristics, and these have often been associated with novel metabolites. These compounds can inhibit successful settlement and survival of algae [homarine (Fig. 1,18), Targett et al. 1983] and sessile epifauna [Ritschoff et al. 1985; renillafoulins (Fig. 1,19), Keifer et al. 1986; pukalide (Fig. 1,10), Gerhart et al. 1988] on these octocorals. Certain metabolites including brianthein-W (Fig. 1,20), found within Briareum sp., have been shown to have insecticidal properties (Cardellina et al. 1984).

Some diterpenes involved in anti-fouling are effective against both adult and larval forms or marine organisms (Ritschoff et al. 1985, Keifer et al. 1986, Gerhart et al. 1988).

\section{Reproduction}

The chemical aspects of gorgonian reproduction have not been studied in detail thus far A review of compounds found within these organisms, however, has revealed the presence of pukalide (Fig 1,10) (Gerhart et al. 1988) and epoxy-pukalide (Fig. 1,21) (Ksebati et al. 1984) These compounds have been found to occur within the eggs, but not the tissue, of the alcyonacean genus Sinularia (Coll et al. 1989). It is possible that they play a similar role within the Gorgonacea, although this remains to be experimentally confirmed.

\section{Chemotaxonomy}

Secondary metabolites in the Gorgonacea have been used to establish phylogenetic relationships between various members of the order (Gerhart 1983). This has resulted in a cladistically deduced chemotaxonomic phylogeny, which agrees well with relationships established using conventional taxonomic techniques (Bayer 1981). This was accomplished despite some of the potential drawbacks associated with chemotaxonomy (Sammarco \& Coll 1988, p. 108-109). These include: (1) the publication of only novel compounds in the chemical literature by investigators, rather than details of all secondary metabolites found in an organism; and (2) the increase in resolution of analytical chemistry over the past 20 years, implying that in organisms analysed years ago with older technology, many compounds may have been missed.

\section{CO-EVOLUTION}

\section{The Alcyonacea}

\section{Mimicry}

Mimicry is defined as the close resemblance of one organism (the mimic) to another (the model) by which a third organism (the operator) is deceived (see Brower 1969, Pianka 1983). Usually the mimic is a prey organism, heavily preyed upon by one species of predator, which resembles a second morphologically similar model species which is toxic, distasteful, or possesses some degree of protection from the predator which the mimic does not have.

Batesian mimicry is specifically the close resemblance of a palatable or harmless mimic to an unpalatable or venomous model in order to deceive a predator (see Lincoln et al. 1982, Pianka 1983, also see Brower 1960, and McNaughton \& Wolf 1979 for general discussion). The mimic gains protection by association or 
similarity. The predator generally learns the morphological (or other) patterns of the model toxic prey, associates a negative feeding response with it, and in turn transfers this association to the mimic.

Here we define Diffuse Batesian Mimicry (Sammarco \& Coll 1988) as the close resemblance of a very large number of unpalatable or toxic models belonging to a single taxon and a similar number of palatable or harmless mimics, thereby affording protection to the taxon as a whole by association or similarity.

Toxicity, palatability, and physical attributes associated with predator defense vary considerably across the Alcyonacea. The trade-off between chemical and physical defense discussed earlier is not as obvious as one might suspect. One reason for this could be that these compounds play a number of roles other than predator defense (see Sammarco \& Coll 1990). We also believe, however, that a second mechanism, not exclusive of the first, may also be operating. That is, this clouded association between morphology and ichthyotoxicity may represent a form of protection by association: Diffuse Batesian Mimicry.

A large proportion of alcyonaceans possess toxins. These species fall into only a few general morphological types (e.g. branching, encrusting or massive upright). Within each category, there are probably as many toxic as non-toxic examples. In addition, many species across genera are similar in appearance, and the variance in toxicity within genera is often as high as that between genera (Coll et al. 1982b, Coll \& Sammarco 1983). This combination of traits may well serve as a blanket deterrent to generalist predators for the order as a whole, because of the difficulties associated with a predator learning to identify acceptable food choices by visual cue alone.

\section{Co-evolved feeding relationships}

In some cases, specialist soft coral predators such as Chaetodon melannotus feed upon some of the most ichthyotoxic octocoral species with impunity (Randall 1967. Anderson et al. 1981, Motta 1988, Alino 1989).

Chaetodon melannotus, a specialist predator, identifies its soft coral prey via visual cues (Alino et al. 1989, Alino 1989). It further modifies its food choice on the basis of the chemistry (Alino et al. in press). This predator is most likely co-adapted to detoxify the secondary metabolites present in its food, much like Ovula ovum (Coll et al. 1983) and Cyphoma gibbosum (Gerhart 1986). Alino (1989) and Alino et al. (in press) demonstrated that none of the original diterpenes known to be present in the soft coral could be found in the fecal pellets of fish feeding on this soft coral. The fish appears to be capable of metabolizing these compounds.
Toxicity and reproduction

Two major forms of sexual reproduction in the Octocorallia are brooding and spawning with external fertilization. Although spawned eggs of many species have been shown to contain significant amounts of terpenoid metabolites, they do not appear to possess effective feeding deterrents (Bowden et al. 1985). The survival of reproductive propagules in this group appears to arise not from chemical defense but from predator satiation. Eggs are often released in a multispecies mass spawning event, encompassing both scleractinian and octocoral species alike (Harrison et al. 1984, Babcock et al. 1986, Alino \& Coll 1989).

Many of the non-spawning species, including Clavularia inflata, Pachyclavularia violacea, and Briareum stechei, brood their developing larvae on the surface of the parent colony where they are openly exposed to predators. It has now been shown that the planulae of $C$. inflata possess significant feeding deterrent properties, as determined through studies of the highly specialized octocoral predator Chaetodon melannotus. The planulae of $P$. violacea and $B$. stechei both have bright brownish-red coloring, similar morphology, and are also surface-brooded. The planulae have not, however, been assessed for feeding deterrent properties (Alino 1989).

Colonies of Pachyclavularia violacea are well defended chemically and possess diterpenoid compounds related to Structure 22 (Fig. 1). As assessed by Gambusia affinis bioassays, the aqueous extracts are ichthyotoxic and confer significant feeding deterrent properties on regular fish food. By contrast, Briareum stechei, which also contains diterpenes like Structure 23 (Fig. 1), is almost totally benign under both assay systems (Alino 1989). Because of the common co-occurrence of these species, $B$. stechei planulae may be protected from predation by association with toxic $P$. violacea planulae through Diffuse Batesian Mimicry. Clavularia inflata spawns 2 wk later than $P$. violacea and $B$. stechei, does not have similar morphology to the other brooding planulae, and so, possesses its own suite of feeding deterrents including Structures 11 and 12 (Fig. 1). This represents an interesting area for continued research.

\section{The Gorgonacea}

Several studies have examined the co-adapted associations between gorgonians and selected predators. In particular, Gerhart (1986) has demonstrated that the gastropod Cyphoma gibbosum is immune to prostaglandins found within its prey - Plexaura homomallain the Caribbean. 
The same gorgonacean is also known to release chemicals which act as kairomones. In this case, the hydrozoan Millepora complanata responds to the presence of these compounds by directed growth towards, and eventual overgrowth of, the gorgonian to enhance its colony size and vertical growth rate (Wahle 1980).

Where secondary metabolites of organisms interact with marine larvae or adults, the ultimate effect may not necessarily be negative for the affected organism. For example, cembranolides [including eunicin (Fig. 1,15)] derived from gorgonian octocorals are known to immobilize veliger larvae of the nudibranch Phestilla sibogae. This nudibranch is a natural, co-adapted predator of these gorgonians. It has been proposed that this is a mechanism by which settlement of this veliger on the gorgonian is enhanced, allowing it to mature on its natural prey. In this way, the probability of the offspring locating a suitable and ample supply of food is increased (Hadfield \& Ciereszko 1978).

\section{COMPARISON OF SOME ADAPTATIONS IN THE OCTOCORALLIA AND THE SCLERACTINIA}

\section{Evolutionary background}

Grasshoff (1984) claims both that the Octocorallia and the Hexacorallia (to which the Scleractinia belong) were derived from a primitive Anthozoan ancestor with a multi-mesentarial polyp [but see Schmidt (1974) for alternate hypothesis]. According to Grasshoff, the split between these 2 major taxa occurred during the early Triassic (245 million years ago). During this period, the Hexacorallia apparently split into a number of groups, one of which was the Scleractinia. This point in geological time represented a point of great radiation for both the Octocorallia and the Scleractinia.

\section{Nematocysts}

One difference between the 2 groups involves evolution of the cnidoblast or stinging cell, a unique coelenterate feature. In the Scleractinia, stinging nematocysts perform at least 2 functions: food capture (Barnes 1974) and aggression or defense against sessile neighbors in competition for space [see Lang \& Chornesky (1990) for review].

Highly potent toxins are often associated with specific types of coelenterate nematocysts. The specialized cells assist in prey capture (usually zooplankton) using proteinaceous toxins and assist competition for space by effecting extracoelenteric digestion of other sessile benthic organisms. Nematocysts may be associated with specialized morphological structures, such as extruded mesenterial filaments or sweeper tentacles.

By contrast, the Octocorallia generally lack stinging nematocysts (e.g. mastigophores) and therefore do not use proteinaceous toxins for prey capture. Instead they possess rhabdoidic heteronemes ( $\beta$-rhabdoids; Schmidt 1974) and utilize atrichous isorhizas or glutinants to entangle their prey (Meglitsch 1972). Recent evidence has demonstrated, however, that some species, including the Indo-Pacific Briareum stechei (Alino 1989) and the Caribbean B. asbestinum (Sebens \& Miles 1988) are indeed capable of producing sweeper tentacles and killing their neighbors. The frequency of occurence of this defence mechanism within the Gorgonacea is not yet known.

The role of secondary metabolites in prey capture by octocorals remains to be investigated. To date, there is no evidence for it.

\section{Toxins and refuge}

Branching scleractinian corals provide structural refuge for associated organisms such as fish. Octocorals, although lacking these structural attributes, can provide a chemically mediated refuge for some fish. In the case of Abudefduf leucogaster (Pisces) in Papua, New Guinea, this is effected through the release of toxic sesquiterpenes including palustrol (Fig. 1,24) by the soft coral Litophyton viridis (Coelenterata, Anthozoa), stimulated by direct contact with the fish (Tursch 1982).

The Octocorallia are generally characterized by an abundance of secondary metabolites with varying functions. The Scleractinia have not been studied as thoroughly for secondary compounds. Evidence is now emerging which demonstrates that bioactive secondary compounds are present in the Scleractinia as well. Sakai \& Higa (1987) have found a compound, tubastrene (Fig. 1,25), with anti-viral activity in the scleractinian coral Tubastrea aurea. Further evidence of secondary metabolites from within the Scleractinia, however, remains scant. This area is only now opening up and deserves further investigation.

\section{BIOGEOGRAPHY: CARIBBEAN VERSUS INDO- PACIFIC OCTOCORALS}

\section{Distribution in the Recent}

Both the Octocorallia and the Scleractinia have pantropical distributions (Levinton 1981). Not all orders within each, however, are equitably distributed between the Caribbean and the Western Pacific. In the 
Indo-Pacific, the Alcyonacea are the most conspicuous and abundant group of octocorals - particularly the families Nephtheidae, Siphonogorgidae, and the Alcyoniidae (Wells 1957). The orders Stolonifera and Telestacea may also be commonly found there. In the shallow waters of the Caribbean, the Gorgonacea are the best represented - particularly the families Gorgonidae, Plexauridae, and Muriceidae (Bayer 1957). The Alcyonacea are all but absent in the Caribbean.

As is the case with many benthic marine organisms (Stehli \& Wells 1971, Goldman \& Talbot 1976, Vermeij 1978. Stanley 1979, Briggs 1987), the family, generic, and species diversity of corals, both soft and hard, is much higher in the Indo-Pacific than in the Caribbean (Bayer 1957). With respect to the Scleractinia, there are at least 80 genera and 700 species in the Indo-Pacific, but only 26 genera and $\geq 60$ species in the Atlantic (Wells 1957, 1973, Goreau \& Wells 1967). For example, the scleractinian Acropora alone has about 70 species in the Indo-Pacific, but only 3 in the Caribbean. With respect to alcyonacean octocorals, there are $>90$ species of the Indo-Pacific genus Sinularia alone; in the Caribbean, there are 3 alcyonacean species. As with the scleractinians, there is little if any overlap in species between Indo-Pacific and Caribbean octocorals.

\section{Links between species diversity and chemical diversity}

The question arises as to whether the selective advantage conferred upon the Alcyonacea by their chemistry has contributed to their differential evolutionary success in the Indo-Pacific when compared to the Gorgonacea in the Atlantic. The answer may well be 'yes', but 'contributed to' would be the appropriate phrase, rather than 'responsible for'. The question must be considered in the context of other important influencing factors - particularly historical ones.

The benthic marine fauna of the tropical Western Atlantic have experienced several major perturbations and extinctions within the past 25 million years. During the pre-Miocene ( $>25$ million years ago), the Scleractinia were known to have a pan-Tethyan distribution, and the fauna of the western Pacific and the western Atlantic were apparently quite similar (Rosen 1978, Stanley 1979, Veron 1986). Two sets of extinctions occurred since that time in the Caribbean. The first occurred in the early Miocene with the closing of the Isthmus of Panama; this separated the Indo-Pacific from the newly formed Atlantic (Rosen 1978, Stanley 1979, 1984, Veron 1986). The second was associated with the late Pliocene/early Pleistocene, accompanying the onset of the last major glaciation (Stanley 1979, 1981, 1984, 1985, 1986). Both events were associated with major climatic and oceanic cooling.

Many scleractinian species suffered extinction through both the first (Wells 1956) and second (Dana 1975, Frost 1977 ) events in the Caribbean but not in the Indo-Pacific. Kuhlmann (1985) explains that the generally north-south orientation of the Rocky Mountains allowed the southerly advance of continental ice without significant obstacle. The generally east-west orientation of the Eurasian mountan ranges - from the Pyrenees through the Himalayas to the Aleutians - are believed to have deterred southerly migration of the glaciers in that part of the world. Parts of the Atlantic apparently cooled considerably in comparison to the Indo-Pacific, causing extincton of various genera of corals (e.g. Fungia, Pocillopora, Stylophora, Montipora, etc.). In addition, the Indo-Pacific Ocean covers one third of the Earth, and the tropical Indo-Pacific is an order of magnitude larger than the tropical Atlantic. The differential thermal capacities of these 2 bodies of water must have also contributed to the differential cooling. Atlantic locations farther south near Brazil served as refuges, and corals are believed to have reinvaded the Caribbean from there after this last glacial epoch.

Such extinctions represent a significant phyletic bottleneck for the Caribbean, leaving fewer species behind from which further radiation could continue. We believe that major extinctions experienced by the scleractinians in the Caribbean were also experienced by the octocorals. This, of course, is difficult to document, because the Octocorallia generally do not fossilize well (Tasch 1973), with several exceptions (Bayer 1957, Konishi 1982).

The reasons for the differential evolutionary success of the major octocoral groups in the 2 regions are complex. Based upon the geological history of the 2 regions, ecological requirements for the taxon, and paleontological evidence drawn from sister taxa, we propose that these differences are closely linked to concepts which led Sanders (1969) to propose the Time-Stability Hypothesis (also see Klopfer 1959, Klopfer \& MacArthur 1960 , 1961, Slobodkin \& Sanders 1969). Over long periods of geological time, the Alcyonacea experienced broad taxonomic radiation in the Indo-Pacific. The reduced climatic perturbations experienced in this geographic region facilitated this radiation in many benthic marine taxa.

The Alcyonacea may have experienced a higher degree of extinction in the Caribbean than the Gorgonacea. The Gorgonacea have a broader latitudinal distribution than the Alcyonacea and, as a group, would appear to be more tolerant of lowered temperatures than the Alcyonacea.

The same processes which allowed the Alcyonacea to radiate taxonomically in the Indo-Pacific also 
allowed them to radiate chemically with respect to their secondary chemistry. The intraspecific diversity of compounds can be quite high in this group, let alone interspecific or intergeneric (Faulkner 1984, 1986, 1987, 1988, 1990, 1991, Hochlowski et al. 1984). The total gene pool available to the taxon for producing a wide range of secondary metabolites in the Caribbean would have been more limited.

\section{Links between chemical diversity and functional diversity of secondary metabolites}

We propose that the same process which has permitted radiation in the diversity of secondary metabolites in the Indo-Pacific has also permitted radiation in their function (Sammarco \& Coll 1988, 1990). At the moment, the only functions defined in the Caribbean Gorgonacea thus far are ecological - feeding deterrence and anti-fouling. It is possible that the relative brevity of this list is due to a more limited number of studies on the Gorgonacea in this region; but we believe that this is only part of the answer.

A latitudinal cline in species diversity, with higher species diversity occurring in the tropics, is certainly as well documented as the longitudinal one discussed above (Fischer 1960, Stehli 1968, Stehli et al. 1969). A similar latitudinal cline in the frequency of occurrence in toxicity was originally suggested by Bakus (1974), and Bakus \& Green (1974), based on work on sponges and holothurians. Although this suggestion has more recently come into question (McClintock 1987), data derived from the Octocorallia confirms that the diversity of the secondary metabolites is higher in the tropics than in the temperate regions (Faulkner 1977, 1984, 1986, 1987, 1988, 1990, 1991). It is not known whether a longitudinal cline in toxicity also exists, for the question has not yet been directly addressed.

\section{AREAS FOR FUTURE RESEARCH}

Although our knowledge of the chemical ecology of octocorals has increased in recent years, there are still numerous unanswered questions to be addressed. We have identified several general areas requiring attention, including:

(1) The possible use of secondary metabolites by octocorals as a mechanism for food capture;

(2) The possible use of secondary metabolites in the Gorgonacea as allelopathic agents;

(3) The possible use of secondary metabolites in the Gorgonacea in reproduction, particularly as sperm attráctants;
(4) The separation of function in various secondary metabolites found within a single octocoral species, and in different tissues within a colony;

(5) The possible function of octocoral secondary metabolites as anti-microbial agents (bacteria, virus, and fungus - marine and other);

(6) The chemotaxonomy of Indo-Pacific Alcyonacea, beginning with individual families;

(7) The testing of hypotheses concerning Diffuse Batesian Mimicry in octocorals and their brooded planulae;

(8) The mechanisms by which octocoral terpenes act on scleractinian cells and tissue at the cytological and biochemical levels and their target sites; and

(9) An analysis of molecular structure and stereochemistry in octocoral secondary metabolites as they relate to known ecological and physiological functions.

Acknowledgements. This manuscript has benefited from discussions with J. Pandolfi and J. E. N. Veron concerning some of the concepts presented here. R. H. Richmond, C. L. Hunter, D. Alongi, V.J Paul and several anonymous reviewers also offered valuable comments on the manuscript. This research was financed by support to both authors from an Australian Marine Sciences and Technology Advisory Committee Grant and an Australian Research Council Grant. The following institutions also assisted in enabling the writing of this review: the Australian Institute of Marine Science, James Cook University of North Queensland, the University of Central Queensland, the Resource Assessment Commission (Department of Prime Minister and Cabinet) and the Louisiana Universities Marine Consortium. To all we are grateful.

\section{LITERATURE CITED}

Alino, P. M. (1989). Ecological and chemical aspects of interactions of soft corals (Octocorallia, Coelenterata). Ph.D. dissertation, James Cook University of North Queensland, Townsville

Alino, P. M. Coll, J. C. (1989). Observations of the synchronized mass spawning and post-settlement activity of octocorals on the Great Barrier Reef, Australia: biological aspects. Bull. mar. Sci. 45: 697-707

Alino, P. M., Sammarco, P. W., Coll, J. C. (1989). Studies on the feeding preferences of Chaetodon melannotus (Pisces) for soft corals (Coelenterata, Octocorallia). Proc. 6th int. coral Reef Congr., Townsville 3: 31-36

Alino, P. M., Sammarco, P. W., Coll, J. C. (1992). Competitive strategies in soft corals (Coelenterata: Octocorallia). IV. Environmentally induced reversals in competitive superiority. Mar. Ecol. Prog. Ser. 81: 129-145

Alino, P. M., Sammarco, P. W., Coll, J. C. (in press). Toxic prey discrimination in highly specialized predators: visual vs chemical cues as determinants. J. exp. Mar. Biol. Ecol.

Anderson, G. R., Ehrlich, A. H., Ehrlich, P. R., Roughgarden, J. D., Russell, B. C., Talbot, F. H. (1981). The community structure of reef fishes. Am. Nat. 117: 476-495

Babcock, R. C., Bull, G., Harrison, P. L., Heyward, A. J., Oliver, J. K., Willis, B. (1986). Synchronous spawnings of 
105 scleractinian coral species on the Great Barrier Reef Mar. Biol. 90: 379-394

Bakus, G. J. (1974). Toxicity in holothurians: a geographic pattern. Biotropica 6: 229-236

Bakus, G. J., Green, G. (1974). Toxicity in sponges and holothurians: a geographic pattern. Science 185: 951-953

Bakus, G. J., Targett, N. M., Schulte, B. (1986). Chemical ecology of marine organisms: an overview. J. chem. Ecol 12: $951-987$

Barnes, R. D. (1974). Invertebrate zoology. W B. Saunders Publ., Philadelphia

Bayer, F. M. (1957). Recent octocorals. In: Hedgpeth, J. W. (ed.) Treatise on marine ecology and paleoecology, Vol. I, Ecology. Geol. Soc. Am., Mem. 67, Boulder, CO, p. 1105-1108

Bayer, F. M. (1981). Key to the genera of Octocorallia exclusive of Pennatulacea (Coelenterata, Anthozoa) with diagnosis of new taxa. Proc. Biol. Soc. Wash. 94: 902-947

Benayahu, Y., Loya, Y (1977). Space partitioning by stony corals, soft corals, and benthic algae on the coral reefs of the northern Gulf of Eilat (Red Sea). Helgoländer Meeresunters. 30: 362-382

Bowden, B. F., Coll J. C., Tapiolas, D. M., Willis, R. H. (1985). Some chemical aspects of spawning in alcyonacean corals. Proc. 5th int. coral Reef Congr., Tahiti 6: 325-329

Briggs, J. (1987). Biogeography and plate tectonics. Elsevier, Amsterdam

Brower, J. V. Z. (1960). Experimental studies of mimicry. IV. The reactions of starlings to different proportions of models and mimics. Am. Nat: 271-282

Brower, L. P. (1969). Ecological chemistry. Sci. Am. 220: 22-29

Cardellina, J. H. II, James, T R. Jr, Chen, M. H. M., Clardy, J. (1984). Structure of brianthein $W$, from the soft coral Briareum polyanthes. J. org. Chem. 49: 3398-3399

Ciereszko, L. S., Karns, T. K. B. (1973). Comparative biochemistry of coral reef coelenterates. In: Jones, O. A., Endean, R. (eds.) Biology and geology of coral reefs, Vol. II, Biology 1. Academic Press, New York, p. 183-203

Coll, J. C. (1981). Soft coral research at James Cook University of North Queensland. Proc. Fourth Asian Symp. of Medicinal Plants and Spices, Bangkok. UNESCO Special Publ., Paris, p. 197-204

Coll, J. C., Alino, P. M., Sammarco, P. W. (1988). The importance of competitive interactions in the dominance of octocorals at Pandora Reef, north Queensland. Austral. mar. Sci. Ass. Conf., Univ. Sydney. Australian Marine Science Association, Brisbane (Abstract)

Coll, J. C., Bowden, B. F., Clayton, M. (1990). Chemistry and coral reproduction. Chem. Britain 26: 761-763

Coll, J. C., Bowden, B. F., Heaton, A., Scheuer, P. J., Li, M. K W., Clardy, J., Schulte, G. K., Finer-Moore, J (1989). Structures and possible functions of pukalide and epoxypukalide; diterpenes associated with eggs of sinularian soft corals (Cnidaria, Anthozoa, Octocorallia, Alcyonacea, Alcyoniidae). J. chem. Ecol. 15: 1177-1191

Coll, J. C., Bowden, B. F., Tapiolas, D. M., Dunlap, W. C. (1982a). In situ isolation of allelochemicals released from soft corals (Coelenterata: Octocorallia): a totally submersible sampling apparatus. J. exp. mar. Biol. Ecol. 60 293-299

Coll, J. C., Bowden, B. F., Tapiolas, D. M., Willis, R. H., Djura, P., Streamer, M., Trott, L. (1985). Studies of Australian soft corals - XXXV. The terpenoid soft corals and its implications. Tetrahedron 41: 1085-1092

Coll, J. C., La Barre, S., Sammarco, P. W., Williams, W. T., Bakus, G. J. (1982b). Chemical defences in soft corals (Coelenterata: Octocorallia) of the Great Barrier Reef: a study of comparative toxicities. Mar. Ecol. Prog. Ser. 8 $271-278$

Coll, I. C., Price, I. R., Konig, G. M., Bowdien, B. F (1987). Algal overgrowth of alcyonacean soft corals. Mar. Biol. 96 129-135

Coll, J. C., Sammarco, P. W. (1983). Terpenoid toxins of soft corals (Cnidaria, Octocorallia): their nature, toxicity, and ecological significance. Toxicon, Suppl. 3:69-72

Coll, J. C., Skelton, B. W., White, A. H., Wright, A. D. (1988) Tropical marine algae. II. The structure determination of new halogenated monoterpenes from Plocamium hamatum (Rhodophyta, Gigartinales, Plocamiaceae). Austral. J. Chem. 41.1743-1753

Coll J. C., Tapiolas, D. M., Bowden, B. F., Webb, L., Marsh, H. (1983). Transformation of soft coral (Coelenterata: Octocorallia) terpenes by Ovula ovum (Mollusca: Prosobranchia). Mar. Biol. 74: 35-40

Dana, T. F. (1975). Development of contemporary eastern Pacific coral reefs. Mar. Biol. 33: 355-374

De Nys, R., Coll, J. C., Price, I. R. (1991). Chemically mediated interactions between the red alga Plocamium hamatum (Rhodophyta), and the soft coral Sinularia cruciata (Alcyonacea). Mar. Biol. 108: 315-320

Dinesen, Z. D. (1983). Patterns in the distribution of soft corals across the central Great Barrier Reef. Coral Reefs 1: 229-236

Faulkner, D. J. (1977). Interesting aspects of marine natural products chemistry. Tetrahedron 33: 1421-1443

Faulkner, D. J. (1984.) Marine natural products: metabolites from marine invertebrates. Nat. Prod. Rep. 1: 551-598

Faulkner, D. J. (1986). Marine natural products. Nat. Prod Rep. 3: 1-33

Faulkner, D. J. (1987). Marine natural products. Nat. Prod Rep. 4: $539-576$

Faulkner, D. J. (1988). Marine natural products. Nat. Prod. Rep. 5: 613-663

Faulkner, D. J. (1990). Marine natural products. Nat. Prod. Rep. 7: 269-309

Faulkner, D. J. (1991). Marine natural products. Nat. Prod. Rep. 8: 97-147

Fenical, W., Okuda, R. K., Bandurraga, M. M., Culver, P., Jacobs, R. S. (1981). Lophotoxin: a novel neuromuscular toxin from Pacific sea whips of the genus Lophogorgia. Science 212: 1512-1513

Fischer, A. G. (1960). Latitudinal variations in organic diversity. Evolution 14:64-81

Frost, S. H. (1977). Miocene to Holocene evolution of Caribbean Province reef-building corals. Proc. 3rd int. Coral Reef Symp., Miami 2:353-359

Gerhart, D. J. (1983). The chemical systematics of colonial marine animals: an estimated phylogeny of the order Gorgonacea based on terpenoid characters. Biol. Bull. 164: $71-81$

Gerhart, D. J (1984). Prostaglandin $A_{2}$ : an agent of chemical defense and evolutionary ecology in the Caribbean gorgonian Plexaura homomalla. Mar. Ecol. Prog. Ser. 19: $181-187$

Gerhart, D. J. (1986). Gregariousness in the gorgonian-eating gastropod Cyphoma gibbosum: tests of several possible causes. Mar. Ecol. Prog. Ser. 31: 255-263

Gerhart, D. J., Rittschof, D. J, Mayo, S. W. (1988). Chemical ecology and the search for marine anti-foulants. J. chem. Ecol. 14: 1905-1917

Goldman, B., Talbot, F. H. (1976). Aspects of the ecology of coral reef fishes. In: Jones, O. A., Endean, R. (eds.) Biology and geology of coral reefs, Vol. 3. Academic Press, New York, p. 125-153 
Goreau, T. F., Wells, J. W. (1967). The shallow-water Sclerac tinia of Jamaica: revised list of species and their vertical distribution range. Bull. mar. Sci. 17: 442-453

Grasshoff, M. (1984). Cnidarian phylogeny - a biomechanical approach. Palaeontographica Americana 54: 127-135

Hadfield, M. G., Ciereszko, L. S. (1978). Action of cembranolides derived from octocorals on larvae of the nudibranch Phestilla sibogae. In: Kaul, P. M., Sinderman, C. J. (eds.) Drugs and food from the sea, myth or reality? University of Oklahoma Press, Norman, p. 145-150

Harrison, P. L., Babcock, R. C., Bull, G. D., Oliver, J. K., Wallace, C. C., Willis, B. L. (1984). Mass spawning in tropical reef corals. Science 223: 1186-1189

Harvell, C. D., Fenical, W. (1989). Chemical and structural defenses of Caribbean gorgonians (Pseudopterogorgia spp.). II. Intra-colony localization of defense. Limnol. Oceanogr. 34: 382-389

Harvell, C. D., Fenical, W., Greene, C. H. (1988). Chemical and structural defenses of Caribbean gorgonians ( $P$ seudopterogorgia spp.). I. Development of an in situ feeding assay. Mar. Ecol. Prog. Ser. 49: 287-294

Harvell, C. D., Suchanek, T. H. (1987). Partial predation on tropical gorgonians by Cyphoma gibbosum (Gastropoda). Mar. Ecol. Prog. Ser. 38: 37-44

Hay, M., Pawlik, J. R., Duffy, J. E., Fenical, W. (1989). Seaweed-herbivore-predator interactions - host plant specialization reduces predation on small herbivores. Oecologia 81: 418-427

Hochlowski, J. E., Coll, J. C., Faulkner, D. J., Biskupiak, J. E., Ireland, C. M., Zheng, Q. T., He, C. H., Clardy, J. (1984). Novel metabolites of four Siphonaria species. J. Am. Chem. Soc. 106: 6748-6750

Karlson, R. H. (1980). Alternative competitive strategies in a periodically disturbed habitat. Bull. mar. Sci. 30(4): $894-900$

Kazlauskas, R., Murphy, P. T., Quinn, R. J., Wells, R. J., Schoenholzer, P. (1977). Hippurin-1, an unusual steroid from the gorgonian Isis hippuris. Tetrahedron Lett. 50: $4439-4442$

Keifer, P. A., Rinehart, K. L. Jr, Hooper, I. R. (1986). Renillafoulins antifouling diterpenes from the sea-pansy Renilla reniformis (Octocorallia). J. org. Chem. 51: 4450-4454

Klopfer, P. H. (1959). Environmental determinants of faunal diversity. Am. Nat. 93: 337-342

Klopfer, P. H., MacArthur, R. H. (1960). Niche size and faunal diversity. Am. Nat. 94: 293-300

Klopfer, P. H., MacArthur, R. H. (1961). On the causes of tropical species diversity: niche overlap. Am. Nat. 95: 223-226

Konishi, K. (1982). Alcyonarian spiculite: limestone of soft corals. Proc. 4th int. coral Reef Symp., Manila 1: 643-649

Ksebati, M. B., Ciereszko, L. S., Schmitz, F. J. (1984). 11B, 12B-Epoxypukalide, a furanocembranolide from the gorgonian Leptogorgia setacea. J. Nat. Prod. 47: 1009-1012

Kuhlmann, D. H. H. (1985). Living coral reefs of the world. Arco Publ., New York, p. 21-22

La Barre, S. C., Coll, J. C. (1984). Movement in soft corals: An interaction between Nephthea brassica (Coelenterata: Octocorallia) and Acropora hyacinthus (Coelenterata: Scleractinia). Mar. Biol. 72: 119-124

La Barre, S. C., Coll, J. C., Sammarco, P. W. (1986a). Chemical defenses in soft corals (Coelenterata: Octocorallia) of the Great Barrier Reef. II. The relationship between toxicity and feeding deterrence. Biol. Bull. 171: 565-576

La Barre, S. C., Coll, J. C., Sammarco, P. W. (1986b). Competitive strategies of soft corals (Coelenterata: Octocorallia) III. Spacing and aggressive interactions between alcyonaceans. Mar. Ecol. Prog. Ser. 28: 147-156
Lang, J. C., Chornesky, E. A. (1990). Competition between scleractinian reef corals: a review of mechanisms and effects. In: Zubinsky, Z. (ed.) Ecosystems of the world: coral reefs. Elsevier, Amsterdam, p. 209-252

Lee, W. Y., Macko, S. A., Ciereszko, L. S. (1981). Toxic effects of cembranolides derived from octocorals of the rotifer Brachionus plicatilis Muller, and the amphipod Parhyale hawaiensis Dana. J. exp. mar. Biol. Ecol 34:91-96

Levinton, J. S. (1981). Marine ecology. Prentice-Hall Publ., Englewood Cliffs

McClintock, J. B. (1987). Investigation of the relationship between invertebrate predation and biochemical composition, energy content, spicule armament and toxicity of benthic sponges at McMurdo Sound, Antarctica. Mar. Biol. 94: 479-487

McNaughton, S. J., Wolf, L. L. (1979). General ecology. Holt, Rinehart, and Winston, New York

Meglitsch, P. A. (1972). Invertebrate zoology. Oxford Press, New York

Motta, P. J. (1988). Functional morphology of the feeding apparatus of kin species of Pacific butterfly fishes (Perciformes, Chaetodontidae): an eco-morphological approach. Environ. Biol. Fish. 22: 39-67

Nishihira, M. (1981). Interactions of Alcyonaria with hermatypic corals on an Okinawan reef flat. Proc. 4th int. coral Reef Symp., Manila 1: 722

Pass, M. A., Capra, M. F., Carlisle, C. H., Lawn, I., Coll, J. C. (1989). Stimulation of contractions in the polyps of the soft coral Xenia elongata by compounds extracted from other alcyonacean soft corals. Comp. Biochem. Physiol. 94-C: $677-681$

Pawlik, J. R., Burch, M. T., Fenical, W. (1987). Patterns of chemical defense among Caribbean gorgonian corals: a preliminary survey. J. exp. mar. Biol. Ecol. 108: 55-66

Pianka, E. R. (1983). Evolutionary ecology. Harper and Row, New York

Randall, J. (1967). Food habits of reef fishes of the West Indies. Stud. Trop. Oceanogr. 5: 665-847

Rittschoff, D., Hooper, I. R., Costlow, J. D. (1985). Barnacle settlement inhibitors from sea pansies, Renilla reniformis Bull. mar. Sci. 39: 376-382

Rosen, D. E. (1978). Vicariance patterns and historical explanation in biogeography. Syst. Zool. 27: 159-188

Sakai, R., Higa, T. (1987). Tubastrine, a new guanidinostyrene from the coral Tubastrea aurea. Chem. Lett. 1: 127-128

Sakemi, S., Higa, T. (1987). 2,3-Dihydrolinderazulene, a new bioactive azulene pigment from the gorgonian Acalycigorgia sp. Experientia 43:624-625

Sammarco, P. W., Coll, J. C. (1988). The chemical ecology of alcyonarian corals (Coelenterata: Octocorallia). In: Scheuer, P. J. (ed.) Bioorganic marine chemistry, Vol. 2. Springer-Verlag, Berlin, p. 87-116

Sammarco, P. W., Coll, J. C. (1990). Lack of predictability in terpenoid function: multiple roles and integration with related adaptations in soft corals. J. chem. Ecol. 16: 273-289

Sammarco, P. W., Coll, J. C., La Barre, S. C. (1985). Competitive strategies of soft corals (Coelenterata: Octocorallia). II. Variable defensive response and susceptibility to scleractinian corals. J. exp. mar. Biol. Ecol. 91: 199-215

Sammarco, P. W., Coll, J. C., La Barre, S. C., Willis, B. (1983). Competitive strategies of soft corals (Coelenterata: Octocorallia). Allelopathic effects on selected scleractinian corals. Coral Reefs 1: 173-178

Sammarco, P. W., La Barre, S., Coll, J. C. (1987). Defensive strategies of soft corals (Coelenterata: Octocorallia) of the Great Barrier Reef. III. The relationship between ichthyotoxicity and morphology. Oecologia 74: 93-101 
Sanders, H. L. (1969). Benthic marine diversity and the stability-time hypothesis. In: Diversity and stability in ecological systems. Brookhaven National Laboratory Symp. 22. Brookhaven National Laboratory, Upton, NY, p. $71-81$

Schmidt, H. (1974). On evolution in the Anthozoa. Proc. 2nd int. coral Reef Symp., Brisbane, 1: 533-560

Sebens, K. P., Miles, J. S. (1988). Sweeper tentacles in a gorgonian octocoral: morphological modifications for interference competition. Biol. Bull. 175: 378-387

Stanley, S. M. (1979). Macroevolution: pattern and process. W. H. Freeman, San Francisco, p. 289-301

Stanley, S. M. (1981). Neogene mass extinction of Western Atlantic mollusks. Nature, Lond. 293: 457-459

Stanley, S. M. (1984). Mass extinctions in the ocean. Sci. Am. 250: $46-54$

Stanley, S. M. (1985). Climatic cooling and Plio-Pleistocene mass extinction of mollusks around the margins of the Atlantic. S. Afr. J. Sci. 81: 266

Stanley, S. M. (1986) Anatomy of a regional mass extinction Plio-Pleistocene decimation of the Western Atlantic bivalve fauna. Palaios 1: 17-36

Stehli, F. G. (1968). Taxonomic gradients in pole location: the recent model. In: Drake, E. T (ed.) Evolution and environment. Yale Univ. Press, New Haven, p. 163-227

Stehli, F. G., Douglas, R. G., Newell, N. D. (1969). Generation and maintenance of gradients in taxonomic diversity. Science 164: $947-949$

Stehli, F. G., Wells, J. W. (1971). Diversity and age patterns in hermatypic corals. Syst. Zool. 20: 115-126

Targett, N. M., Bishop, S. S., McConnell, O. J., Yoder, J. A. (1983). Antifouling agents against the benthic marine diatom Navicula salinicola: homarine from the gorgonian Leptogorgia virgulata and $L$. setacea, and analogues. J. chem. Ecol. 9: 817-829

Tasch, P. (1973) Paleobiology of the invertebrates. Data retrieval from the fossil record. John Wiley and Sons, New York

This review was submitted to the editor
Theodor, J. L. (1966), Contribution à l'étude des gorgones (v): les greffes chez les gorgones. Bull. Inst. Oceanogr. Monaco 66 (1374): 1-7

Theodor, J. L. (1971). Reconnaissance de 'self' ou reconnaissance du 'not self' Arch. Zool. Exp. Gen. 112: 113-116

Theodor, J. L. (1975). Comment les gorgones distinguent le 'soi' du 'non-soi'. La Recherche 6: 573-575

Tursch, B. (1982). Chemical protection of a fish (Abudefduf leucogaster Bleeker) by a soft coral (Litophyton viridis May). J. chem. Ecol. 8: 1421-1428

Tursch, B., Braekman, J. C., Daloze, D., Kaisin, M. (1978). Terpenoids from coelenterates. In: Scheuer, P. J. (ed.) Marine natural products: chemical and biological perspectives, Vol. II. Academic Press, New York, p. 247-296

Vermeij, G. J. (1978). Biogeography and adaptation, patterns of marine life. Harvard Univ. Press, Cambridge

Veron, J. E. N. (1986). Corals of Australia and the Indo-Pacific Angus and Robertson, Sydney

Wahle, C. M. (1980). Detection, pursuit and overgrowth of tropical gorgonians by milleporid hydrocorals: Perseus and Medusa revisited. Science 209: 689-691

Wells, J. W. (1956). Scleractinia. In: Moore, R. C. (ed.) Treatise on invertebrate paleontology, Part F, Coelenterata. Geol. Soc. Am., Boulder, $\mathrm{CO}$, and Univ. Press of Kansas, Lawrence (joint publ.), p. 328-444

Wells, J. W. (1957). Coral reefs. In: Hedgpeth, J. W. (ed.) Treatise on marine ecology and paleoecology, Vol. I, Ecology. Geol. Soc. Am., Mem. 67, Boulder, CO, p. 609-631

Wells, J. W. (1973). New and old scleractinian corals from Jamaica. Coral Reef Project - Papers in memory of Dr. Thomas F. Goreau. 2. Bull. mar. Sci. 23(1): 16-58

Wylie, C. R., Paul, V. J. (1989). Chemical defenses in three species of Snularia (Coelenterata, Alcyonacea) - effects against generalist predators and the butterfly fish Chaetodon unimaculatus Bloch. J. exp. Mar. Biol. Ecol. 129: $141-160$

Yamanouchi, $T$ (1955). On the poisonous substances contained in holothurians. Publs. Seto Mar. Lab. 4: 183-283

Manuscript first received: March 27, 1992

Revised version accepted: September 10, 1992 